\title{
An Elective Course in Women's Health Issues
}

Natalie A. DiPietro, PharmD, MPH; Associate Professor of Pharmacy Practice

Ohio Northern University Raabe College of Pharmacy, Ada, $\mathrm{OH}$

Disclosures: No conflicts of interest to disclose

Keywords: women's health, pharmacy, curricula, elective

Note Added in Proof: An updated women's health curriculum guide was released for comment in August 2013 at the AACP Annual Meeting.

A copy can be found online at:

http://www.aacp.org/governance/SIGS/womenfaculty/Documents/2013\%20June\%20Womens\%20Health\%20Curriculum\%20Task\%20Force\%20Report\%20.pdf

\begin{abstract}
Purpose: To develop, implement, and evaluate an elective course for the Doctor of Pharmacy (PharmD) curriculum that provides students with a comprehensive overview of women's health across the lifespan and exposes them to social and economic issues that impact women's health. Case Study: At the time of this writing, the class has been delivered 3 times to a total of 56 students. Students read and discussed (both in-class and online) timely articles in women's health issues on topics including sex-based biology; women in clinical trials; maternal and child health; women's health coverage and access to care in the United States; gender and health communication; abuse and the role of healthcare professionals; and international issues in women's health and women's rights. Students completed a pre-and post-test; developed seminar presentations regarding women's health issues; wrote reflective essays about the course; and designed and implemented health promotion projects for National Women's Health Week (NWHW). At the end of the course, the number of correct answers on the post-test significantly improved from the pre-test (p<0.001). Through anonymous course evaluations, students indicated that the assignments fulfilled the learning objectives (mean 4.68 on a 5 -point Likert scale) and the exercises were useful in helping their understanding of the material (mean 4.66 on a 5-point Likert scale). Over 500 women from the campus and community participated in the NWHW projects. Implications: An elective course was designed to educate pharmacy students regarding women's health issues and to provide students with an opportunity to perform community outreach.
\end{abstract}

\section{Introduction}

As accessible and trusted healthcare professionals, pharmacists are often making recommendations or counseling female patients about their health concerns, as well as the health conditions of their family members. Therefore, it is necessary that pharmacy students receive adequate knowledge and training through the Doctor of Pharmacy (PharmD) curriculum to be able to fulfill this vital role. Students must understand the diseases that disproportionately affect women, as well as sex-specific guidelines for primary and secondary prevention. Concepts such as sex-based biology and the lifespan approach to women's health must be introduced. ${ }^{1,2}$ Students must also be aware of potentially important differences between men and women in the experience of disease and response to medications ${ }^{1-3}$, and the sex-based differences in enrollment into certain clinical trials and in analysis of data. ${ }^{4}$ Similarly, students should appreciate the unique social and economic considerations that may influence a woman's health, such as caretaking responsibilities, access to healthcare, communication styles, and issues of abuse. All of this information, taken in context, can be utilized by future pharmacists to improve patient-specific and populationbased outcomes.
The pharmacy academy has recognized the importance of educating students on topics pertinent to women's health. The American Association of Colleges of Pharmacy (AACP), in collaboration with four governmental agencies, has released a comprehensive "Gender and Sex-Related Health Care Pharmacy Curriculum Guide", which recommended key concepts to be included in the didactic education of Doctor of Pharmacy (PharmD) students. ${ }^{5}$ In order to fulfill some of the content in the curriculum guide, an elective course may be useful.

This elective course in women's health issues was developed to augment the knowledge gained through required therapeutics courses regarding disease presentation in women and pharmacological/non-pharmacological recommendations. In addition, the course afforded students the opportunity to learn about additional topics, such as international issues in women's health, that they likely did not receive exposure to previously. The purpose of this course was to educate students on some of the core elements outlined in the AACP Gender and Sex-Related Health Care Pharmacy Curriculum Guide and to provide them with opportunities to put this knowledge into practice 
through activities such as active learning exercises and community outreach programs.

\section{Course Content and Design}

The 2-credit hour elective course introduced PharmD students to timely and important topics in women's health primarily through a discussion-based approach led by the course instructor. Course objectives, adapted from the AACP Gender and Sex-related Health Care Pharmacy Curriculum Guide $^{5}$, are listed in Table 1.

Table 1. Course objectives

Upon completion of this course, the student should be able to do the following, as adapted from the AACP Gender and Sex-related Health Care Pharmacy Curriculum Guide ${ }^{5}$ :

$>$ Explain the differences between the terms "gender" and "sex" as they apply to practice and research.

$>$ Describe the basis for sex-based biology. Demonstrate a basic understanding of diseases/conditions and drug-related effects that specifically affect women and those that affect women and men differently.

$>$ Discuss the history of regulatory issues related to gender and sex-related healthcare. Discuss issues regarding the recruitment of adequate numbers of women in clinical trials and informed consent issues for the inclusion of women in research studies.

$>$ Demonstrate knowledge of pregnancy planning and preconception care. Discuss all contraceptive methods including abstinence, natural family planning, prescription \& nonprescription contraceptive methods, and emergency contraception.

$>$ Demonstrate an understanding of how women's decisions about health for themselves and their families effect their spending in the marketplace.

$>$ Discuss insurance issues that affect women's ability to access healthcare in the U.S.

$>$ Demonstrate an understanding of how healthcare professionals should interact with female patients and different communication styles.

$>$ Discuss physical, sexual, and mental abuse, including caregiver abuse, and the role of healthcare professionals in recognizing abuse.

$>$ List international issues in women's health and women's rights.

Table 2 outlines the topics covered in the course. Students were presented with a comprehensive overview of women's health across the lifespan and were introduced to topics such as the biological basis for sex-related differences and subsequent health outcomes; the involvement of women in clinical trials; and maternal and child health. Students also educated each other about select diseases that differentially or disproportionately affect women and treatment of certain disease states during pregnancy. Students were exposed to social and economic issues that impact women's health in the U.S. and internationally. In general terms, the first half of the course focused on scientific and medical aspects of women's health; the remaining weeks covered the political, social, and economic aspects of women's health. Appendix 1 lists useful resources for each of these topics.

\section{Table 2. Course outline}

$>$ Explanation of course and requirements

$>$ In-class assignment: Pre-test

$>$ Women's health: The lifespan approach

$>$ Introduction to sex-based biology

$>$ Overview of diseases that disproportionately or differentially affect women

$>$ Women in clinical trials: History \& considerations

$>$ Overview of pharmacokinetic and pharmacodynamic differences between men and women

$>$ Introduction to maternal \& child health

$>$ Preconception \& interconception care

$>$ Family planning

$>$ Drug use during pregnancy: Registries and surveillance systems

$>$ Student seminars

$>$ Women as healthcare decision-makers and influencers

$>$ Women's health coverage and access to care in the U.S.

$>$ Gender and health communication

$>$ Recognizing physical, sexual, mental, and caregiver abuse and the role of healthcare professionals

$>$ International issues in women's health and women's rights

$>$ In-class assignment: Post-test

At the time of this writing, the course has been offered 3 times, once during an academic year. Students in their $3^{\text {rd }}$, $4^{\text {th }}$, or $5^{\text {th }}$ year of a 0-6 PharmD program were eligible to enroll in the course. The class was held in 2 consecutive 50minute sessions 1 day per week. The following assignments and activities were utilized to assess whether the students met the course objectives: pre/post-test; reflections on the reading assignments; in-class discussions and active-learning activities; research and presentation of a scientific seminar; design and implementation of a project for National 
Women's Health Week; and a reflective essay. Each of these is further described below.

Before the course began, the instructor created a test consisting of fill-in-the-blank and short answer essay questions. The questions evaluated students' knowledge regarding the course content based upon the course objectives (Table 1). The test was administered as a pre-test on the first day of the course; the same test was administered as a post-test during the final class meeting. The pre/posttests were kept by the instructor, but students were able to view the feedback to their responses on these tests. The preand post-tests were non-graded events. As students enrolled in the course are at different points in the pharmacy curriculum, the pre-test provided the instructor with insight into the baseline knowledge of the cohort regarding women's health issues. Although the course content did not change based upon the results of the pre-test, it alerted the instructor to particular areas that may require additional time or attention. A comparison of performance on the pre- and post-tests allowed both student and instructor to gauge the knowledge gained through the course and to determine whether any deficiencies still existed.

Each week of the course focused on a topic as outlined in Table 2. Approximately 3 articles pertaining to each week's topic were posted to WebCT, the university's course management software. The students read the articles and were requested to post a reflection or reaction to the articles each week. (There were no postings for the weeks in which the students present their scientific seminars.) The students could write about new insights they had obtained from the readings and could react to other's postings. Students were informed that a 3 to 5 sentence (minimum) post would be acceptable. The readings were posted to WebCT one week before the postings were due. The posting was due on the day that class was held, by noon (3 hours before class began). The purpose of the WebCT postings were twofold: 1) to ensure that students had completed and critically evaluated the reading before class, which would enhance their participation in discussion and other activities, and 2) to allow the instructor to introduce points of discussion based in part upon the WebCT postings (e.g. to highlight issues that students had written that they were surprised to learn about, or that they had found to be confusing). The WebCT postings accounted for $25 \%$ of the student's final grade in the course; the instructor ensured that each student had completed the postings and evaluated the content for analysis and relevance to the week's topic.

The instructor utilized in-class discussions and active learning techniques to review the weekly topics with the students. As students shared views and opinions on numerous topics, some of which are sensitive or controversial, it was critical that the classroom be an open and safe environment.

"Ground rules" were shared with the students on the first day of class and reinforced at key points throughout the course. As a result, students were able to express thoughts and opinions in a professional and respectful atmosphere without personal attacks or unprofessional comments or behavior. The instructor used a variety of methods to lead the discussion, such as the posing of a particular question to generate student conversation or utilizing open-ended questions to ask the students what they thought were particularly salient areas to discuss. Active learning was also implemented in almost all of the class sessions. For example, students worked in group to complete recommendations for patient case scenarios (created by the instructor) based on preconception care guidelines. Fifteen percent of the student's final course grade was based on attendance and participation in the in-class discussions and active learning activities.

As part of the course, students were required to research, develop, and present a 10-minute scientific seminar containing information pertinent to one of the following areas: 1 ) a disease state or condition that disproportionately or differentially affects women; 2) a pharmacokinetic or pharmacodynamic difference between men and women; or 3) treatment of a particular disease state or use of a particular drug class during pregnancy and lactation. By the end of the second week of class, each student submitted to the instructor via email his/her first choice for a presentation topic, as well as two alternates. Within a few days, the instructor confirmed the topic with each student, ensuring that a variety of appropriate topics were presented in class. Each student created a PowerPoint presentation to convey the information about his/her topic. All PowerPoint presentations were due to be posted to WebCT on the same day, though the in-class presentations occurred on different dates. Each student gave his/her seminar to the rest of the class, providing an opportunity for peer-teaching. Following the presentation, students were able to ask questions. The instructor was also able to verbally clarify any inconsistences or oversights in the information that was provided, although this rarely happened. The seminar counted as $20 \%$ of the final grade for the course and was graded by the instructor on the following attributes: accuracy of information (20 points); completeness of information (20 points); quality of information and appropriate references (20 points); format of PowerPoint slides (15 points); presentation flow and delivery (15 points); length of presentation and adequate response to questions (10 points). 
For National Women's Health Week (NWHW), students worked in teams of 3-4 to create a program or project, under the supervision of the instructor, to implement on campus or in the community. NWHW is coordinated by U.S. Department of Health and Human Services' Office on Women's Health and starts with Mother's Day each year. ${ }^{6}$ During NWHW, women are encouraged to prioritize their health and to take steps to improve health and prevent disease. Students decided the topic and nature of their project focusing on either primary prevention (e.g., health education) and/or secondary prevention (e.g., screening programs). The teams also selected the venue(s) for their project. The instructor provided contact information for community centers and pharmacies that the College of Pharmacy had ongoing relationships with for student outreach programs; students could also decide to use a different venue and were then responsible for initiating contact with the site. As part of the project, students registered the events on the NWHW website. They were also advised to order materials and utilize the media outreach tools available on the NWHW website. Press releases were created and submitted to the local media highlighting NWHW and the upcoming projects. After the program was implemented, students submitted to the instructor brief forms that collected metrics about the project and measured individual and team members' contributions to the group work (Appendix 2). While it is a group project, each student earned an individual grade, which contributed $20 \%$ to the final course grade. The instructor assessed the projects based on the quality of the program and its materials (20 points); students' abilities to interact with participants and answer questions (15 points); and the students' abilities to collaborate in teams (15 points). During the final class session, student groups informally shared with the class the design, outcomes, and lessons learned from their project.

Finally, students wrote a 5-7 page reflective essay as a culminating experience in the course. Each student described important concepts and insights obtained through the course and the projected impact on his/her professional practice. The paper was graded by the instructor for content (30 points) as well as proper format, grammar, and spelling (20 points). The score on the reflective essay provided $20 \%$ of the student's course grade.

\section{Student Performance}

At the time of this writing, a total of 56 students had completed the course over 3 academic years. Each of the assignments (i.e. pre/post-test, seminar, reflective essay, WebCT postings, NWHW project), as well as the in-class discussion and active learning activities provided the instructor with opportunities to evaluate the students' progress on meeting the course objectives. The pre/post- tests assessed whether any changes in student knowledge related to the course objectives occurred through participating in the course. Matched pre-and post-tests were available for 47 of the 56 students (84\%). The paired t-test (IBM SPSS Statistics 20) was utilized to assess whether differences in pre-test scores and post-test scores were statistically significant. Students' knowledge significantly improved between pre- and post-test $(p<0.001)$.

The seminar experience not only provided the students with comprehensive information regarding varied women's health issues, but also gave them another occasion to deepen their expertise in literature retrieval and evaluation and to further develop their presentation skills. Most students performed very well in the seminars both in the content they were providing and their delivery style, with about $80 \%$ of the students scoring a $90 \%$ or higher.

The WebCT postings and reflective essays allowed students to express their understanding of the material. Oftentimes, students would post reflections to WebCT that were much longer than the minimum requirement. Many reacted to other student's writings, indicating that students were reading other's postings. The reflective essays were thoughtful and well-written, with most students providing good detail on the impact of the course to them as future pharmacists. Over the years, nearly $86 \%$ of the students have earned a $90 \%$ or higher on this assignment.

The NWHW project served to provide students an opportunity to interact with the general public regarding wellness and health promotion, a key role for pharmacists. Through the development and implementation of the project, students utilized the scientific knowledge and the information on health communication with women that they were gaining through the course. Table 3 describes the various NWHW projects the students have implemented and summarizes the number of women on the campus or in the community who participated. Every year, press releases regarding the NWHW projects were published in university and community newspapers, and public service announcements were created and broadcast from the university's radio station. In addition, one year the instructor and several students were interviewed for segments on the university's radio station and the local NBC affiliate television station, which served to further disseminate the message about women's health and NWHW. Review of the forms (Appendix 2) submitted by the students indicated that almost all student groups perceived that their teammates contributed equally to the NWHW project. 
Table 3. Summary of NWHW projects implement by students enrolled in the course

\begin{tabular}{|c|c|c|}
\hline Event & Description & Metrics \\
\hline $\begin{array}{l}\text { "Mom } \\
\text { mailings" }\end{array}$ & $\begin{array}{l}\text { - At the student union } \\
\text { building, any interested } \\
\text { student on campus could } \\
\text { put together a packet to } \\
\text { send to his/her mother or } \\
\text { other female friend or } \\
\text { family member. } \\
\text { Students received } \\
\text { Mother's Day cards, } \\
\text { brochures/booklets about } \\
\text { women's health, and } \\
\text { manila envelopes to mail } \\
\text { the materials. }\end{array}$ & $\begin{array}{l}85 \text { packets } \\
\text { distributed }\end{array}$ \\
\hline $\begin{array}{l}\text { Osteoporosis } \\
\text { screening for } \\
\text { campus } \\
\text { faculty and } \\
\text { staff }\end{array}$ & $\begin{array}{l}\text { - Participants received: } \\
\begin{array}{ll}\circ \quad \text { risk assessment } \\
\circ \quad \text { Sahara heal-scan } \\
\circ \quad \text { counseling/ } \\
\\
\text { educational materials }\end{array}\end{array}$ & $\begin{array}{l}28 \text { women } \\
\text { screened }\end{array}$ \\
\hline $\begin{array}{l}\text { Provision of } \\
\text { educational } \\
\text { materials at } \\
\text { health fairs; } \\
\text { grocery } \\
\text { stores; } \\
\text { restaurants; } \\
\text { pharmacies; } \\
\text { community } \\
\text { centers; } \\
\text { student } \\
\text { union; } \\
\text { student } \\
\text { cafeteria }\end{array}$ & $\begin{array}{l}\text { - Topics varied by venue } \\
\text { and included: } \\
\circ \quad \text { breast cancer } \\
\circ \quad \text { preconception care } \\
\circ \quad \text { sun safety/skin } \\
\quad \text { cancer } \\
\circ \quad \text { nutrition }\end{array}$ & $\begin{array}{c}413 \text { women } \\
\text { educated }\end{array}$ \\
\hline
\end{tabular}

\section{Student Perceptions}

At the conclusion of the course, students evaluated the elective through anonymous online surveys administered via CoursEval software (ConnectEDU, Boston). Students were asked to assess each question on a scale of Excellent (5) to Poor (1). Fifty of the 56 students (89\%) completed the evaluations; the results are displayed in Table 4.

Fifteen students who completed the course evaluation provided comments in the free text box. Thirteen of the 15 comments were positive: representative comments included "really beneficial class"; "the articles and references that you
Table 4. Student assessment $(n=50)$ of the course where 5=Excellent and 1=Poor.

\begin{tabular}{|l|c|c|}
\hline \multicolumn{1}{|c|}{ Question } & Mean & $\begin{array}{c}\text { +/- Standard } \\
\text { Deviation }\end{array}$ \\
\hline $\begin{array}{l}\text { How well do you feel the } \\
\text { course syllabus explains the } \\
\text { learning objectives? }\end{array}$ & 4.84 & 0.37 \\
\hline $\begin{array}{l}\text { How well do you feel that } \\
\text { the assignments and } \\
\text { projects fulfilled the } \\
\text { learning objectives? }\end{array}$ & 4.68 & 0.51 \\
\hline $\begin{array}{l}\text { Do you feel that the overall } \\
\text { flow of the material made } \\
\text { sense? }\end{array}$ & 4.64 & 0.49 \\
\hline $\begin{array}{l}\text { Do you feel that the } \\
\text { discussions and exercises } \\
\text { were useful in helping your } \\
\text { understanding of the } \\
\text { material? }\end{array}$ & 4.66 & 0.58 \\
\hline $\begin{array}{l}\text { Do you feel that the } \\
\text { experience of having } \\
\text { presented a seminar was } \\
\text { useful in preparing you for } \\
\text { other formal presentations } \\
\text { in your career? }\end{array}$ & 4.74 & 0.45 \\
\hline $\begin{array}{l}\text { Did you find listening to } \\
\text { and participating in other } \\
\text { student's seminars useful } \\
\text { and interesting? }\end{array}$ & 4.74 & 0.45 \\
\hline
\end{tabular}

chose were really interesting"; "I appreciated the chance to discuss issues"; "I enjoyed the course and believe that it will make me more prepared to be a pharmacist who can attend to certain patients' needs". Two students provided constructive criticism. One student thought that there was "too much reading" for a "slow reader". Another student suggested quizzes over the readings as additional opportunities to earn points in the class.

As this class utilized the standardized course evaluation surveys that are used for all College of Pharmacy courses, the NWHW projects were not specifically assessed via this method. However, several students did provide comments on the required NWHW forms (Appendix 2), which indicated that they found the projects to be good practice for working with future patients.

\section{Lessons Learned}

The course has several strengths. This type of course provides time to explore important issues in women's health, such as the history of women in clinical trials, women's health policy, and international issues in women's health, that may not 
covered in great detail in therapeutics courses. Students are able to research a women's health topic of interest to them and to educate members of the community about specific women's health issues. Assessment of individual and group assignments indicated that the course was effective in meeting the learning objectives.

Course content is continually updated as new data and developments regarding women's health issues arise. Types and provision of emergency contraception is one example of a topic area that continues to change. Another example is the issue of healthcare reform and potential implications to women regarding access to healthcare and insurance coverage. A new active learning activity is also being planned for the topic of elder abuse. The instructor has been recently made aware of the Center of Excellence of Elder Abuse and Neglect and will have the students watch the videos on their website during class to identify examples of elder abuse portrayed by the actors. ${ }^{7}$

Additionally, over the years that the instructor has offered the course, certain elements of the course have evolved. For example, the percentage that each assignment contributes to the final course grade has been revised. Likewise, Part 2 of the NWHW forms (Appendix 2) has become more robust over time. The instructor has neither modified the number of readings nor introduced quizzes into the course based on the limited number of students requesting such a change; however, if additional students make similar recommendations in the future, these changes will be considered.

There are at least two potential limitations to this course in its current version. The class was created as an elective course to supplement the women's health information students received through required therapeutics modules; therefore, not every aspect of the AACP Gender and Sexrelated Health Care Pharmacy Curriculum Guide ${ }^{5}$ is addressed in this course. The fact that the post-test is not a graded event may also be perceived as a limitation; while the students demonstrated understanding and insight of women's health issues through several graded assignments, their ability to recall information was not graded.

\section{Implications}

Women's health is an important topic area that colleges and schools of pharmacy must address through curricula. This elective course has provided pharmacy students with an understanding of sex-based biology and other physiological, social, and economic factors that impact female patients. In addition, through this course, programs have been implemented in the community to raise awareness on a number of women's health issues.

This case study provides just 1 example of how content regarding women's health issues may be structured. Reviewing recent publications of other women's health courses $^{8,9}$ in addition to this case study may be helpful to one interested in introducing a new course or revising an existing course as his or her institution.

\section{References}

1. Institute of Medicine. Exploring the biological contributions to human health: Does sex matter? Washington, DC: National Academy Press, 2001.

2. Institute of Medicine. Women's health research: Progress, pitfalls, and promise. Washington, DC: National Academy Press, 2010.

3. General Accounting Office. Drug safety: Most drugs withdrawn in recent years had greater health risks for women, 2001. http://www.gao.gov/new.items/d01286r.pdf. Accessed February 28, 2013.

4. General Accounting Office. Women sufficiently represented in new drug testing, but FDA oversight needs improvement, 2001. http://www.gao.gov/new.items/d01754.pdf. Accessed February 28, 2013.

5. American Association of Colleges of Pharmacy and US Department of Health and Human Services (US DHHS) Health Resources and Services Administration (HRSA). Gender and sex-related health care pharmacy curriculum guide, 2003.

http://www.aacp.org/resources/education/Docume nts/GenderandSexRelatedHCCurriculumGuide.pdf Accessed February 28, 2013.

6. US Department of Health and Human Services. National Women's Health Week.

www.womenshealth.gov/WHW/. Accessed February 28, 2013.

7. Center of Excellence of Elder Abuse and Neglect, University of California, Irvine. Reaching important gatekeepers: Training pharmacists about elder abuse

http://www.centeronelderabuse.org/Kaiser Pharma cy.asp

8. Marshall LL, Ashworth LE. An elective course in women's health. American Journal of Pharmaceutical Education, 2010;74(1):Article 12.

9. Yuksel N. Pharmacy course on women's and men's health. American Journal of Pharmaceutical Education, 2011:75(6):Article 119. 


\section{Appendix 1. Useful resources}

- General

- Borget LM, O'Connell MB, Smith JA, Calis KA, eds. Women's Health Across the Lifespan: A Pharmacotherapeutic Approach. Bethesda, MD: American Society of Health-Systems Pharmacists, 2010.

- Centers for Disease Control and Prevention (CDC). Women's health. http://www.cdc.gov/women/

- Correa-de-Araujo R. A wake-up call to advance women's health. Women's Health Issues 2004;14(2):31-34.

- Food and Drug Administration (FDA) Office of Women's Health http://www.fda.gov/AboutFDA/CentersOffices/OC/OfficeofWomensHealth/default.htm

- National Institutes of Health (NIH) Office of Research on Women's Health http://orwh.od.nih.gov/

- Senie RT. Epidemiology of Women's Health. Burlington, MA: Jones and Bartlett Learning, 2014.

- US Department of Health and Human Services (US DHHS) Office of Women's Health http://www.womenshealth.gov/

- Sex-based biology; Lifespan approach to women's health

- Institute of Medicine. Exploring the Biological Contributions to Human Health: Does Sex Matter? Washington, DC: National Academy Press, 2001.

- Institute of Medicine. Women's Health Research: Progress, Pitfalls, and Promise. Washington, DC: National Academy Press, 2010.

- NIH Office of Research on Women's Health and FDA Office of Women's Health. The science of sex and gender in human health. Online course available from http://sexandgendercourse.od.nih.gov

- Pinn VW. Sex and gender factors in medical studies: Implications for health and clinical practice. Journal of the American Medical Association 2003;289(4):397-400.

- Women in clinical trials

- FDA Women's participation in clinical trials http://www.fda.gov/ScienceResearch/SpecialTopics/WomensHealthResearch/ucm131731.htm

- General Accounting Office (GAO) Report "Drug safety: Most drugs withdrawn in recent years had greater health risks for women", 2001. http://www.gao.gov/new.items/d01286r.pdf

- GAO Report "Women sufficiently represented in new drug testing, but FDA oversight needs improvement", 2001. http://www.gao.gov/new.items/d01754.pdf

- Society for Women's Health Research http://www.womenshealthresearch.org/site/PageServer

- Maternal and child health; Family planning

- American Public Health Association Policy Database. Policy Number 201114 Reducing U.S. maternal mortality as a human right http://www.apha.org/advocacy/policy/policysearch/default.htm?id=1430

- Cabral K, Gianutsos G. Pharmacists' role when plan A fails. US Pharmacist http://www.uspharmacist.com/continuing education/ceviewtest/lessonid/107866/

- CDC Maternal and infant health http://www.cdc.gov/reproductivehealth/maternalinfanthealth/index.htm

- CDC. Safe motherhood http://www.cdc.gov/nccdphp/publications/aag/pdf/drh.pdf

- CDC. Preconception health and care http://www.amchp.org/Calendar/Documents/At\%20a\%20Glance\%20PCC.pdf

- FDA Contraceptive guide http://www.fda.gov/downloads/ForConsumers/ByAudience/ForWomen/FreePublications/UCM282014.pdf

- FDA Pregnancy registries http://www.fda.gov/ScienceResearch/SpecialTopics/WomensHealthResearch/ucm251314.htm

- The Guttmacher Institute http://www.guttmacher.org/

- Kaiser Family Foundation. Emergency contraception. http://kff.org/womens-health-policy/fact-sheet/emergencycontraception/

- Pharmacist's Letter. Oral contraceptives. March 2013;Vol:29

- US DHHS Health Resources and Services Administration (HRSA). Maternal and child health http://mchb.hrsa.gov/ 
- Social, political, and economic issues in women's health

- Kaiser Family Foundation. Women's health policy www.kff.org/womenshealth/index.cfm

- National Partnership for Women and Families http://www.nationalpartnership.org/site/PageServer

- National Women's Law Center http://www.nwlc.org/

- Health communication with female patients

- $\quad$ CDC Health communication http://www.cdc.gov/healthcommunication/healthbasics/whatishc.html

- Nussbaum JF, Ragan S, Whaley B. Children, older adults, and women: Impact on provider-patient interaction. In: Thompson TL, Dorsey AM, Miller KI, Parrott R eds. Handbook of Health Communication Mahwah, NJ: Lawrence Erlbaum, 2003.

- Roter DL, Hall JA, Aoki Y. Physician gender effects in medical communication: A meta-analytic review. Journal of the American Medical Association 2002;288(6):756-764.

- Recognizing abuse and the role of healthcare professionals

- US DHHS Agency for Healthcare Research and Quality (AHRQ). Women and domestic violence: Programs and tools that improve care for victim http://archive.ahrq.gov/research/domviolria/domviolria.htm

- CDC. Understanding sexual violence http://www.cdc.gov/violenceprevention/pub/SV factsheet.html

- $\quad$ Center of Excellence of Elder Abuse and Neglect, University of California, Irvine. Reaching important gatekeepers: Training pharmacists about elder abuse http://www.centeronelderabuse.org/Kaiser Pharmacy.asp

- Institute of Medicine. Confronting Chronic Neglect: The Education and Training of Health Professionals on Family Violence. Washington, DC: National Academy Press, 2002.

- Plichta SB. Intimate partner violence and physical health consequences: Policy and practice implications. Journal of Interpersonal Violence 2004;19(11):1296-1323.

- US DHHS Office of Women's Health. Elder abuse http://womenshealth.gov/aging/safety-abuse/elder-abuse.cfm

- US DHHS Office of Women's Health. Violence against women http://womenshealth.gov/violence-against-women/

- International issues in women's health and women's rights

- Buvinic M, Medici A, Fernandez E, Torres AC. Gender differentials in health. In: Jamison DT, Breman JG, Measham AR, et al, eds. Disease Control Priorities in Developing Countries, 2 ed. Washington, DC: World Bank; 2006.

- International Women's Health Coalition http://www.iwhc.org/index.php

- United Nations. Millennium Development Goals www.un.org/millenniumgoals/

- United Nations - WomenWatch http://www.un.org/womenwatch/

- World Health Organization. Women's health http://www.who.int/topics/womens health/en/ 


\section{Appendix 2. Forms Completed by Students to Document National Women's Health Week Projects}

Teams could decide to complete Form 1 together and submit just 1 copy. However, every student had to complete Form 2 individually. All forms were submitted directly to the instructor.

\section{Form 1 - Metrics on Impact of Women's Health Week Project}

Names of team member(s)

In the space below, please write a description of your project. Be sure to provide details such as the date/time and location of your project and a description of how your project was implemented. Is there anything you would do differently the next time you conduct a community outreach program? (Use back of page if necessary)

In the space following each question, indicate metrics to describe your project's impact. These metrics should include the following information, as applicable:

1) total number of hours volunteered by your student team

2) number of individuals who participated in your project

3) any other metrics that may be pertinent to your project or any feedback you may have received on the project (use back of page if necessary) 
Form 2: Measure of Contributions to Women's Health Week Project

Name

Please answer each question below using the following scale:

1=Strongly Agree; 2=Agree; 3=Not sure; 4=Disagree; 5=Strongly Disagree.

If for any question you answered a " 4 " or " 5 ", please provide additional information in Section 3.

\section{Section 1: Measure of individual contribution:}

1. I am pleased with my contribution to the project.

$\begin{array}{lllll}1 & 2 & 3 & 4 & 5\end{array}$

2. I think that my contributions were comparable to the other team members'.

$\begin{array}{lllll}1 & 2 & 3 & 4 & 5\end{array}$

\section{Section 2: Measure of team members' contributions:}

1. Each member of the team contributed his/her share to the project.

1223045

2. It is fair for each member of the team to receive the same grade for the project.

$1 \quad 2 \quad 3 \quad 4 \quad 5$

Section 3: You can use this space to report any additional information or feedback (both positive or negative) not captured above. If you answered a " 4 " or " 5 " to any question, please explain further. You may use back of page if necessary. 